\title{
Biometrical, Biochemical, and Molecular Diagnosis of Portuguese Meloidogyne hispanica Isolates
}

Carla M. Maleita, IMAR-CMA, Department of Life Sciences, University of Coimbra (UC), 3004-517 Coimbra, Portugal; Maria José Simões and Conceição Egas, BIOCANT_-Technology Transfer Center, Advanced Sequencing Services, 3060-197 Cantanhede, Portugal; Rosane H. C. Curtis, Plant Pathology and Microbiology Department, Rothamsted Research, Harpenden, Hertfordshire, AL5 2JQ, UK; and Isabel M. de O. Abrantes, IMAR-CMA, UC, Portugal

\begin{abstract}
Maleita, C. M., Simões, M. J., Egas, C., Curtis, R. H. C., and Abrantes, I. M. de O. 2012. Biometrical, biochemical, and molecular diagnosis of Portuguese Meloidogyne hispanica isolates. Plant Dis. 96:865-874.

Meloidogyne hispanica infects many economically important crops worldwide. The accurate identification of this pathogen is essential for the establishment of efficient and sustainable integrated pest management programs. Portuguese $M$. hispanica isolates were studied by biometrical, biochemical, and molecular characteristics. Biometrical characteristics of $M$. hispanica females, males, and second-stage juveniles were similar to the original description. Biochemical studies revealed a unique enzyme pattern (Hi4) for $M$. hispanica esterases that allowed for species differentiation. Molecular analysis of the mtDNA region from $C O I I$ and 16S rRNA genes resulted in amplification products $(1,800 \mathrm{bp})$ similar to $M$. hispanica, M. ethiopica, and M. javanica, and the described HinfI was unable to discriminate M. hispanica from

the other two species. Analysis of the mtDNA sequences revealed altered nucleotides among the isolates that created new restriction sites for AluI and DraIII. The resulting restriction patterns successfully discriminated between the three species, providing a new tool for Meloidogyne identification. Finally, the phylogenetic relationship between $M$. hispanica and several Meloidogyne spp. sequences was analyzed using mtDNA, confirming the divergence between meiotic and mitotic species and revealing the proximity of $M$. hispanica to closely related species. Based on the studies conducted, the application of isozyme or polymerase chain reaction restriction fragment length polymorphism analysis would be a useful and efficient methodology for $M$. hispanica identification.
\end{abstract}

The "Seville root-knot nematode", isolated from peach rootstock (Prunus persica (L.) Batsch) in Spain, was studied for the first time by Dalmasso and Bergé (17) and described later as Meloidogyne hispanica Hirschmann, 1986 (27). This species has a worldwide distribution, and has been reported infecting economically important crops in Africa $(22,34,48)$, Asia (21), Australia (21), Europe $(4,21,31,49)$, and North, Central, and South America $(10,15,21)$.

$M$. hispanica is cytologically similar to the diploid race of $M$. arenaria, and morphologically very close to $M$. arenaria, $M$. floridensis, and $M$. incognita $(13,25,27)$. When tested using the North Carolina differential host test, $M$. hispanica isolates have host responses similar to $M$. arenaria race 2 or $M$. javanica $(4,13), M$. arenaria race 1 or $M$. incognita race $2(4,27)$, and $M$. incognita race 3 (4), showing an intraspecific variability among the isolates of this species. The identification of $M$. hispanica only on the basis of morphological characteristics, especially on perineal patterns, or on the pattern of disease reactions induced in the North Carolina differential hosts, is very difficult. One isolate of $M$. hispanica from South Africa was erroneously associated with $M$. arenaria thamesi on the basis of perineal pattern morphology (34). Therefore, biochemical and molecular markers should be used for differentiating this species from the other Meloidogyne spp. and to confirm or clarify root-knot nematode (RKN) diagnoses made in the past. The biochemical electrophoretic analysis of nonspecific esterases remains one of the first stages in species identification

Corresponding author: C. M. Maleita,

E-mail: carlamnmaleita@ hotmail.com

GenBank accession numbers of nucleotide sequences: JN673274 and JN673275.

Accepted for publication 13 January 2012.

http://dx.doi.org/10.1094/PDIS-09-11-0769-RE

(C) 2012 The American Phytopathological Society when adult females are available $(4,9,12)$. Three phenotypes (Hi2, $\mathrm{S} 2-\mathrm{M} 1=\mathrm{Hi} 3$, and Hi4) have been detected and all the isolates shared two common major bands that have been used to differentiate this species $(4,27,28,35)$.

With the expansion of DNA-based methodologies, new alternatives have been developed and have been shown to be an attractive solution not only for the identification of RKN populations but also to provide important data for phylogenetic analysis. Molecular approaches for distinguishing RKN species have included several techniques, and different regions of the DNA have been studied $(8,38,39,42,51)$. However, isolates of $M$. hispanica have been included in only a few studies $(14,35,37,42)$.

In a study based on restriction fragment length polymorphisms (RFLPs) obtained from amplified mtDNA of Meloidogyne isolates digested with HinfI, the patterns of M. hispanica consisted of two fragments distinct from those of $M$. arenaria, $M$. hapla, $M$. incognita, and $M$. javanica (14). The restriction pattern obtained with the probe, designated as pMiK4, showed two bands common to $M$. arenaria, $M$. hispanica, $M$. incognita, and $M$. javanica (1.6 and 3.0 $\mathrm{kb})$. However, all the species could be distinguished by the presence of a characteristic band for $M$. arenaria at $3.5 \mathrm{~kb}, M$. incognita at $2.0 \mathrm{~kb}, M$. hispanica at $1.5 \mathrm{~kb}$, and $M$. javanica at $0.7 \mathrm{~kb}$ (37). A multiplexed polymerase chain reaction (PCR) test, based on the amplification of Meloidogyne mtDNA with primers MORF, MTHIS, TRNAH, and MRH106 and digested with HinfI or MnlI, differentiated $M$. hispanica from $M$. arenaria, $M$. chitwoodi, $M$. hapla, $M$. incognita, and $M$. javanica (42). Recently, in order to support the specific identification of $M$. hispanica, species-specific PCR and phylogenetic analyses of sequences from three rDNA regions (18S, internal transcribed spacer [ITS]1-5.8S-ITS2, and D2-D3 of 28S) were used to characterize three $M$. hispanica isolates from Brazil, Portugal, and Spain (35).

The purposes of this research were to study extensively seven Portuguese isolates of $M$. hispanica by biometrical, biochemical, and molecular characteristics, and develop a new molecular diagnostic method for the identification and differentiation of $M$. hispanica from other RKN species based on the mtDNA region 
between $C O I I$ and 16S rRNA genes. The phylogenetic relationship of M. hispanica to other Meloidogyne spp. with available mtDNA sequences was also analyzed.

\section{Materials and Methods}

Nematode isolates. Seven isolates of $M$. hispanica were used in this study and another eight Meloidogyne spp. isolates were included in the biochemical and molecular studies for comparison (Table 1). All the isolates used in this study were originally obtained from a single egg mass and maintained on tomato (Solanum lycopersicum L. 'Easypeel') by periodic subculturing in a growth chamber at $25 \pm 2{ }^{\circ} \mathrm{C}$, in the Nematology Laboratory (IMAR-CMA, Department of Life Sciences, University of Coimbra, Portugal).

Biometrical studies. Morphological and morphometrical studies were conducted on second-stage juveniles (J2) and adult males and females of each of the seven isolates of $M$. hispanica (Table 1). Adult males were recovered from infected roots, J2 hatched from egg masses in moist chambers, and adult females handpicked from infected tomato roots. Freshly hatched J2, adult males and females, and perineal patterns were prepared for light microscope studies as previously described by Abrantes and Santos (2) and measured immediately. Photographs were taken with a Leitz Dialux 20 bright field light microscope.

Freshly hatched $\mathrm{J} 2$ and adult males and females were processed for scanning electron microscope studies as described by Abrantes and Santos (2). Perineal patterns of adult females and stylets of J2 and adult males and females were also prepared as described by Abrantes and Santos (1,2) and Eisenback (19). The specimens were mounted on stubs, coated with gold $(200 \AA)$, viewed, and photographed with a JEOL JSM-35C. At least 50 specimens of each life stage, perineal patterns, and excised stylets of $\mathrm{J} 2$ and adult males and females were examined.

Biochemical studies. For isozyme analysis, young egg-laying females (5/tube or 10/tube for PtCh) of each Meloidogyne sp. and isolate (Table 1) were handpicked from infected tomato roots and transferred to micro-hematocrit tubes with $5 \mu$ of extraction buffer $(20 \%$ [wt/vol] sucrose and $1 \%$ [vol/vol] Triton X-100). The specimens were macerated with a pestle, frozen, and stored at $-20^{\circ} \mathrm{C}$. Electrophoresis was performed according to Pais et al. (36) in vertical gels in a Mini-Protean Tetra System (Bio-Rad Laboratories, Hercules, CA). The gels were stained for esterase activity with the substrate $\alpha$-naphthyl acetate. Protein extracts of $M$. javanica young egg-laying females were included in each gel as a reference. Phenotypes were designated with a letter(s) suggesting the nematode species, followed by a number indicating the number of bands (21). Biochemical procedures were repeated every time that the isolates were used in molecular studies.

Molecular studies. DNA extraction. Freshly hatched J2 of each isolate (Table 1), obtained from egg masses, were concentrated by centrifugation for $2 \mathrm{~min}$ at $594 \times g$ and stored at $-20^{\circ} \mathrm{C}$ in Eppendorf tubes. Packed juveniles were placed at $-80^{\circ} \mathrm{C}$ for at least $1 \mathrm{~h}$ before genomic DNA extraction and purification according to Randig et al. (40), with modifications. The J2 were mechanically squashed with a pestle, homogenized, and $91.7 \mu$ l of lysis buffer (0.1 M Tris-HCl, $\mathrm{pH} 8.0 ; 50 \mathrm{mM}$ EDTA; $1 \%$ [wt/vol] sodium dodecyl sulfate; and $0.17 \mathrm{M} \mathrm{NaCl}$ ) and $8.3 \mu \mathrm{l}$ of proteinase $\mathrm{K}(6$ $\mu \mathrm{g} / \mu \mathrm{l})$ was added. After the incubation of the homogenates at $60^{\circ} \mathrm{C}$ for $1 \mathrm{~h}$ and $10 \mathrm{~min}$ at $95^{\circ} \mathrm{C}, 1 \mu \mathrm{l}$ of a solution of ribonuclease $\mathrm{A}$ (Sigma-Aldrich, St. Louis) at $10 \mathrm{mg} / \mathrm{ml}$ was added and the tubes were incubated at $37^{\circ} \mathrm{C}$ for $15 \mathrm{~min}$. DNA was purified with equal volume of phenol/chloroform/isoamyl alcohol (25:24:1) for $1 \mathrm{~min}$, mixed by gentle inversion of the Eppendorf tube, and centrifuged at $14,841 \times g$ for $1 \mathrm{~min}$ at $4^{\circ} \mathrm{C}$. The supernatant was transferred to a new Eppendorf tube, 2.5 volumes of absolute ethanol was added to precipitate the DNA, and the mixture was centrifuged at 14,841 $\times g$ for $20 \mathrm{~min}$ at $4^{\circ} \mathrm{C}$. The precipitate was washed with $500 \mu \mathrm{l}$ of ice-cold $70 \%$ ethanol, and dried at $45^{\circ} \mathrm{C}$ for $\pm 15 \mathrm{~min}$. The DNA was resuspended in $20 \mu \mathrm{l}$ of sterilized distilled water.

Sequencing. Mitochondrial DNA from isolates PtHi3 of M. hispanica and ItE of $M$. ethiopica were sequenced with the primer set C2F3 (5'-GGT CAA TGT TCA GAA ATT TGT GG-3') and MRH106 (5'-AAT TTC TAA AGA CTT TTC TTA GT-3') located in the COII gene and the 16S rRNA gene $(38,42)$. PCR was performed in a $50-\mu$ l volume containing $1 \times$ buffer, $2 \mathrm{mM} \mathrm{MgSO}_{4}, 0.2$ $\mathrm{mM}$ dNTPs, $0.2 \mu \mathrm{M}$ each primer, $2.5 \mathrm{U}$ of Platinum Taq DNA Polymerase (Invitrogen, Life Technologies, Carlsbad, CA), and 100 ng of nematode DNA. Amplifications were carried using the following conditions: an initial denaturation at $94^{\circ} \mathrm{C}$ for $4 \mathrm{~min}$; followed by 35 cycles of denaturation at $94^{\circ} \mathrm{C}$ for $30 \mathrm{~s}$, annealing at $56^{\circ} \mathrm{C}$ for $45 \mathrm{~s}$, and extension at $68^{\circ} \mathrm{C}$ for $2 \mathrm{~min}$; and a final extension for $10 \mathrm{~min}$ at $68^{\circ} \mathrm{C}$. The amplified products were purified with the High Pure PCR Product Purification Kit (Roche Applied Science, Penzberg, Germany) and quantified using the NanoDrop 1000 Spectrophotometer (Thermo Scientific, Wilmington, DE), according to the manufacturer's instructions. Amplified DNA was sequenced in both directions with the same amplification primers and a new intermediate primer due to the high length of the fragment (5'-GAT CGG GGT TTA ATA ATG GG-3'), by standard procedures at Macrogen, Inc. (Seoul, Korea). Chromatograms were checked and corrected manually by use of the freely available online Chromas software (Technelysium Pty Ltd., Brisbane, Australia). The mtDNA sequences of $M$. hispanica and $M$. ethiopica were deposited in GenBank as JN673274 and JN673275, respectively.

Sequences from the PtHi3 and ItE isolates were aligned with ClustalW (45) within BioEdit software (24) with Meloidogyne spp. mtDNA sequences between $C O I I$ and the 16S rRNA genes available in the GenBank nucleotide database (National Center of Bio-

Table 1. Meloidogyne isolates, hosts, geographic origin, and studies where they have been included in this work

\begin{tabular}{|c|c|c|c|c|}
\hline Species (isolate code) ${ }^{a}$ & Host plant & Geographic origin & Reference & Studies $^{b}$ \\
\hline \multicolumn{5}{|l|}{ Meloidogyne hispanica } \\
\hline (PtHi1) & Solanum lycopersicum L. & Coimbra & $\ldots$ & $\mathrm{Mb}, \mathrm{B}$ \\
\hline (PtHi2) & Ficus carica $\mathrm{L}$. & Setúbal & 4 & $\mathrm{Mb}, \mathrm{B}, \mathrm{M}$ \\
\hline (PtHi3) & F. carica $\mathrm{L}$. & Faro & 4 & $\mathrm{Mb}, \mathrm{B}, \mathrm{M}$ \\
\hline (PtHi4; selected from PtHi3) & Capsicum aпnиит $\mathrm{L}$. & $\ldots$ & $\ldots$ & $\mathrm{Mb}, \mathrm{B}, \mathrm{M}$ \\
\hline (PtHi5) & Dianthus caryophyllus L. & Aveiro & 35 & $\mathrm{Mb}, \mathrm{B}, \mathrm{M}$ \\
\hline (PtHi6) & S. tuberosum L. & Santarém & 16 & $\mathrm{Mb}, \mathrm{B}, \mathrm{M}$ \\
\hline (PtHi7) & S. tuberosum L. & Aveiro & 16 & $\mathrm{Mb}, \mathrm{B}, \mathrm{M}$ \\
\hline M. $\operatorname{arenaria}(\mathrm{PtA})$ & Oxalis corniculata $\mathrm{L}$. & Coimbra & $\ldots$ & $\mathrm{B}, \mathrm{M}$ \\
\hline M. chitwoodi $(\mathrm{PtCh})$ & S. tuberosum L. & Porto & 16 & $\mathrm{~B}, \mathrm{M}$ \\
\hline$M$. hapla $(\mathrm{PtH})$ & Alnus glutinosa (L.) Gaertn. & Viana do Castelo & $\ldots$ & $\mathrm{B}, \mathrm{M}$ \\
\hline M. incognita $(\mathrm{PtI})$ & Cucumis melo L. & Açores & $\ldots$ & $\mathrm{B}, \mathrm{M}$ \\
\hline M. javanica $(\mathrm{PtJ})$ & S. tuberosum L. & Guarda & $\ldots$ & $\mathrm{B}, \mathrm{M}$ \\
\hline M. mayaguensis ( $\mathrm{VnM})$ & Malpighia glabra L. & Cabudare & $\ldots$ & $\mathrm{B}, \mathrm{M}$ \\
\hline M. megadora (STMe) & Coffee arabica $\mathrm{L}$. & S. Tomé & $3,5,6$ & $\mathrm{~B}, \mathrm{M}$ \\
\hline M. ethiopica (ItE) & S. lycopersicum L. & Pontecagnano & $\ldots$ & $\mathrm{B}, \mathrm{M}$ \\
\hline
\end{tabular}

a $\mathrm{Pt}=$ Portugal; Vn = Venezuela; ST = Democratic Republic of S. Tomé and Príncipe; It = Italy.

${ }^{\mathrm{b}} \mathrm{B}=$ Biochemical studies; $\mathrm{M}=$ polymerase chain reaction restriction fragment length polymorphism analysis; Mb $=$ morphobiometrial studies. 
technology Information, www.ncbi.nlm.nih.gov). The sequences of PtHi3 and ItE isolates were compared with sequences of $M$. ethiopica, $M$. incognita, and $M$. javanica, because they showed similar products of amplification. We used the freely available online WebCutter 2.0 software to determine restriction enzyme maps based on altered nucleotides between the isolates that created new restriction sites. Enzymes with varied digestion product sizes within Meloidogyne spp. were selected to allow for easier species identification during visualization by agarose gel electrophoresis.

PCR-RFLP. PCR amplification was conducted with the primer set $\mathrm{C} 2 \mathrm{~F} 3$ and MRH106 as already described $(38,42)$. PCR reactions were performed in a $25-\mu \mathrm{l}$ volume containing $1 \times$ buffer, 1.8 $\mathrm{mM} \mathrm{MgCl} 2,0.2 \mathrm{mM}$ dNTPs, $0.2 \mu \mathrm{M}$ each primer, $2.5 \mathrm{U}$ of Taq DNA polymerase (Bioline, London), and $50 \mathrm{ng}$ of nematode DNA. The amplifications were carried out in a MyCycle Thermal Cycler (Bio-Rad Laboratories) using the following conditions: an initial denaturation at $94^{\circ} \mathrm{C}$ for $4 \mathrm{~min}$; followed by 35 cycles of denaturation at $94^{\circ} \mathrm{C}$ for $30 \mathrm{~s}$, annealing at $56^{\circ} \mathrm{C}$ for $45 \mathrm{~s}$, and extension at $72^{\circ} \mathrm{C}$ for $2 \mathrm{~min}$; and a final extension for $10 \mathrm{~min}$ at $72^{\circ} \mathrm{C}$. The PCR reaction $(5 \mu \mathrm{l})$ was analyzed on $1 \%$ agarose gel electrophoresis in $1 \times$ Tris-acetate-EDTA (TAE) buffer stained with ethidium bromide.

Amplification products with approximately $1,800 \mathrm{bp}$ were digested with $5 \mathrm{U}$ of HinfI (Amersham Biosciences, Barcelona, Spain). If no digestion occurred with Hinfl, the amplified products were digested separately with $5 \mathrm{U}$ of $A l u \mathrm{I}$ (USBiological, Swampscott, MA) and DraIII (New England BioLabs Inc., Ipswich, MA). DraIII restriction enzyme was applied in $2 \mu \mathrm{l}$ of PCR products and $H i n f \mathrm{I}$ and $A l u \mathrm{I}$ were applied in $3 \mu \mathrm{l}$ according to the manufacturer's instructions. The digestion was conducted at $37^{\circ} \mathrm{C}$ for $5 \mathrm{~h}$ to DraIII and for $8 \mathrm{~h}$ to HinfI and $A l u \mathrm{I}$ restriction enzymes. Restriction fragments were separated on $2 \%$ agarose gel electrophoresis in $1 \times$ TAE buffer stained with ethidium bromide. Molecular procedures were repeated at least three times to verify the results.

Phylogenetic analysis. The sequences of Meloidogyne spp. from different locations included in the phylogenetic analysis were obtained by searching the GenBank nucleotide database.

Sequences from the PtHi3 and ItE isolates were aligned using Muscle (18) with all sequences or only those of related species with similar amplification products for the mtDNA region studied (M. arabicida, M. ethiopica, M. incognita, and M. javanica). Alignment was manually adjusted when necessary. The length of all sequences of Meloidogyne spp. was set to 1,673 bp by removing several nucleotides to obtain a common start and end point. The phylogenetic relationship was reconstructed using neighbor-joining (NJ) (30) and maximum likelihood (ML) (41) methods. NJ analyses were performed using the Maximum Composite Likelihood model (43) with complete deletion. One thousand bootstrap replicates were performed to test the support of each node on the trees (23). ML analyses were based on the Jukes-Cantor model (30). All positions containing gaps and missing data were eliminated. Alignment and evolutionary analyses were conducted in MEGA5 (44).

\section{Results}

Biometrical studies. Morphometrics of adult females and males and $\mathbf{J} 2$ of the seven Portuguese M. hispanica isolates are reported in Table 2. Adult females of $M$. hispanica showed a globose to ovoid shape with a distinguished neck (128.3 to $303.3 \mu \mathrm{m}$ neck) and without tail protuberance. The body was rounded posteriorly (Fig. 1A) and the cephalic region was slightly prominent, not annulated, and very small when compared with body size (Fig. 1A and B). The stylet length ranged from 11.1 to $19.0 \mu \mathrm{m}$, with the cone curved dorsally, widening gradually posteriorly, the shaft straight, and the knobs with indented anterior margins (Fig. 1C and D). The distance between the stylet base and the dorsal esophageal gland orifice was short to long (2.8 to $6.8 \mu \mathrm{m})$ (Fig. 1B-D). Excretory pore position was variable, 13.2 to $77.9 \mu \mathrm{m}$ from anterior end. Perineal patterns varied from ovoid to rounded (Fig. 1E-G). Dorsal arch was generally low; however some patterns showed a higher and quadrangular arch. Dorsal striae were relatively uniform, smooth, and straight, sometimes wavy. Ventral pattern area gener- ally showed fine and smooth striae. Lateral lines were distinct; some dorsal and ventral striae connected with each other to originate an angle, while others forked. The perivulval region was not striated. Phasmidial ducts were distinct (Fig. 1E and F).

Adult males lengths ranged from $1,400.0$ to $2,357.1 \mu \mathrm{m}$, with the anterior end slightly tapered and the posterior rounded (Fig. 1H-J and L). The labial disc was large, elongated, raised, and fused with the medial lips that were narrow and crescent shaped, with smooth outer margins. The head region was smooth (Fig. 1I and J). The stylet was robust and large with a straight cone, pointed and widening gradually to the posterior end (Fig. 1K). Excretory pore position was variable (147.5 to $240.0 \mu \mathrm{m}$ from anterior end). Spicules were long ( 28.0 to $41.1 \mu \mathrm{m})$ and slightly curved; the gubernaculum was crescent shaped. The tail was short and round, with phasmids generally very close to the level of cloaca (Fig. 1L). The lateral field had four longitudinal incisures.

Body length of $\mathrm{J} 2$ varied from 320.0 to $514.4 \mu \mathrm{m}$, with a truncate head region and a narrow tail region (Fig. $1 \mathrm{M}$ and $\mathrm{Q}$ ). The labial disc was raised and fused with the crescent shaped medial lips. The head region was usually smooth, occasionally with 1 to 3 incomplete annulations (Fig. 1N). The stylet length was 9.2 to 13.0 $\mu \mathrm{m}$, with the cone tip slender, widening gradually to the posterior end; the shaft was cylindrical, widening gradually to the posterior end; and the knobs were rounded to ovoid and separated, sloping posteriorly (Fig. $1 \mathrm{M}$ and $\mathrm{O}$ ). The tail had a rounded tip and the hyaline tail terminus was indistinct. The rectal dilation was large (Fig. 1P and Q).

Biochemical studies. The three esterase bands observed in the $M$. javanica isolate ( $\mathrm{Rm}: 0.37,0.43$, and 0.46 ) were used as a reference isolate to determine the relative position of bands observed in the other Meloidogyne isolates (J3; Fig. 2).

In the M. hispanica isolates studied, four bands of esterase activity (two major bands and two minor and fainter bands) were detected (Rm: 0.32, 0.35, 0.38, and 0.41), corresponding to the phenotype Hi4 (Fig. 2). The identification of the other eight Meloidogyne spp. isolates used for comparison in the molecular studies was confirmed by the esterase phenotypes (Fig. 2; Table 1). In these isolates, 19 bands of esterase activity were observed, comprising eight phenotypes on the basis of single bands or combinations. All of them contained distinct and species-specific phenotypes. The esterase phenotype of $M$. hispanica was clearly distinct from the other Meloidogyne spp. used in this study (Fig. 2).

Molecular studies. The mtDNA COII and 16S rRNA genes region was selected to carry out the molecular characterization of $M$. hispanica isolates. This region, amplified with the primer set C2F3/MRH106 from purified DNA extracted from J2 from each of the Meloidogyne isolates, yielded single fragments of four different sizes (approximately 650, 850, 1,300, and 1,800 bp; Fig. 3). Specifically, the isolates of $M$. hapla and M. chitwoodi (with esterase phenotype H1 and Ch1) had a PCR product of approximately $650 \mathrm{bp}$; the $M$. mayaguensis isolate (M4) produced a fragment of $850 \mathrm{bp}$; the $M$. arenaria isolate (A2) had a fragment of $1,300 \mathrm{bp}$; and the isolates of M. hispanica (Hi4), M. ethiopica (E3), $M$. javanica (J3), and $M$. incognita (I2) gave a fragment of approximately 1,800 bp (Figs. 2 and 3). No amplification occurred with the $M$. megadora isolate (Me3).

When the amplified products of approximately $1,800 \mathrm{bp}$ were digested with the restriction enzyme HinfI, three patterns of digestion were observed but only $M$. incognita was clearly differentiated. Two fragments of approximately 1,300 and $400 \mathrm{bp}$ were produced in the $M$. incognita isolate and two fragments of approximately 1,700 and $100 \mathrm{bp}$ were generated in $M$. hispanica isolates and $M$. ethiopica. No digestion occurred in the $M$. javanica isolate (Fig. 4). Molecular analysis of the mtDNA region, with the described HinfI PCR-RFLP, was unable to discriminate $M$. hispanica from $M$. ethiopica and $M$. javanica. In order to obtain useful information for species discrimination, the PCR products of PtHi3 ( $M$. hispanica) and ItE (M. ethiopica) isolates for the mtDNA region were sequenced and compared with equivalent sequences of $M$. ethiopica and M. javanica available in GenBank. Analysis of the 
nucleotide variation observed in the alignment and the restriction enzyme maps produced in WebCutter revealed that altered nucleotides between the isolates created new restriction sites for the enzymes $A l u \mathrm{I}$ and DraIII. Digestion of the approximately $1,800 \mathrm{bp}$ mtDNA PCR product with $A l u \mathrm{I}$ generated three fragments of approximately $1,000,580$, and $240 \mathrm{bp}$ for $M$. hispanica (six isolates; data shown for only one isolate) and $M$. javanica, while two fragments of approximately 1,240 and 580 bp were observed for $M$. ethiopica (Fig. 5A). On the other hand. DraIII could not digest $M$. hispanica but generated two fragments of approximately 1,000 and $800 \mathrm{bp}$ for M. ethiopica and M. javanica (Fig. 5B).

Phylogenetic analysis. Mitochondrial DNA sequences (which include part of the COII, a variable intergenic region, tRNAHis, and part of the 16S rRNA gene) of PtHi3 (M. hispanica) and ItE ( $M$. ethiopica) isolates were determined and, although the sequences were not complete, the sequence size of the PtHi3 isolate was 1,680 and $1,684 \mathrm{bp}$ in the ItE isolate. The sequences were compared with the corresponding fragments from closely related species which displayed similar amplification products (M. arabicida, M. ethiopica, M. incognita, and $M$. javanica). The PtHi3 sequence differed by 22 nucleotide positions from M. ethiopica (ItE and Me, AY942848), M. incognita from Thailand (FY159614), and $M$. javanica (AY635612). The mtDNA sequences of $M$. ethiopica isolates from Italy (ItE) and Brazil (Me) were similar, with only seven differences in alignment. The differences included nucleotide changes at positions 781, 1055, 1148, and 1624; two insertions at 987 and 1340; and, finally, one deletion at position 58 (data not shown). Amplified product of $M$. arabicida was slightly longer than those of other species, showing several changes, including two insertions between positions 937 and 951 and 1,068 and 1,128, and one deletion between 864 and 892 (data not shown).

Table 2. Morphometric comparison of adult females and males and second-stage juveniles of seven Portuguese Meloidogyne hispanica isolates with original M. hispanica description (Hirschmann 1986)

\begin{tabular}{|c|c|c|c|c|c|c|}
\hline \multirow[b]{2}{*}{ Characteristic } & \multicolumn{2}{|c|}{ Females } & \multicolumn{2}{|c|}{ Males } & \multicolumn{2}{|c|}{ Second-stage juveniles } \\
\hline & $\begin{array}{l}\text { Portuguese } \\
\text { isolates }\end{array}$ & $\begin{array}{c}\text { Hirschmann } \\
1986\end{array}$ & $\begin{array}{l}\text { Portuguese } \\
\text { isolates }\end{array}$ & $\begin{array}{c}\text { Hirschmann } \\
1986\end{array}$ & $\begin{array}{l}\text { Portuguese } \\
\text { isolates }\end{array}$ & $\begin{array}{c}\text { Hirschmann } \\
1986\end{array}$ \\
\hline \multicolumn{7}{|l|}{ Linear $(\mu \mathrm{m})$} \\
\hline Body length & $\begin{array}{l}723.3 \pm 79.2 \\
(570.0-920.0) \\
11.0\end{array}$ & $\begin{array}{l}830.0 \pm 150.4 \\
(570.0-1,180.0) \\
18.1\end{array}$ & $\begin{array}{c}1,846.2 \pm 170.1 \\
(1,400.0-2,357.1) \\
9.2\end{array}$ & $\begin{array}{c}1,677.6 \pm 168.4 \\
(1,340.6-1,990.0) \\
10.0\end{array}$ & $\begin{array}{l}418.4 \pm 28.8 \\
(320.0-514.4) \\
6.9\end{array}$ & $\begin{array}{l}392.6 \pm 18.7 \\
(356.4-441.4) \\
4.8\end{array}$ \\
\hline Body width & $\begin{array}{c}503.8 \pm 62.6 \\
(365.0-660.0) \\
12.4\end{array}$ & $\begin{array}{c}503.0 \pm 108.9 \\
(330.0-740.0) \\
21.6\end{array}$ & $\begin{array}{l}41.6 \pm 4.8 \\
(32.5-58.6) \\
11.7\end{array}$ & $\begin{array}{c}41.1 \pm 3.5 \\
(32.4-47.4) \\
8.4\end{array}$ & $\begin{array}{c}14.6 \pm 1.2 \\
(13.3-17.8) \\
8.0\end{array}$ & $\begin{array}{l}14.5 \pm 0.5 \\
(13.4-15.8) \\
3.7\end{array}$ \\
\hline Neck length & $\begin{array}{l}195.4 \pm 35.5 \\
(128.3-303.3) \\
18.1\end{array}$ & $\begin{array}{l}232.7 \pm 71.7 \\
(140.0-440.0) \\
30.8\end{array}$ & 11.1 & 0.7 & $0.0-2=$ & J.1 $25=$ \\
\hline Neck width & $\begin{array}{l}145.2 \pm 24.3 \\
(93.3-221.7) \\
16.8\end{array}$ & $\begin{array}{l}129.8 \pm 31.6 \\
(60.0-200.0) \\
24.4\end{array}$ & $\cdots$ & $\cdots$ & $\cdots$ & $\cdots$ \\
\hline $\begin{array}{l}\text { Body width at } \\
\text { stylet knobs }\end{array}$ & $\ldots$ & $\ldots$ & $\begin{array}{c}21.7 \pm 1.4 \\
(14.3-25.7) \\
6.3\end{array}$ & $\begin{array}{l}20.3 \pm 0.7 \\
(18.3-21.4) \\
3.6\end{array}$ & $\begin{array}{l}9.3 \pm 0.4 \\
(8.4-10.5) \\
4.5\end{array}$ & \\
\hline $\begin{array}{l}\text { Body width at excretory } \\
\text { pore }\end{array}$ & $\ldots$ & $\ldots$ & $\begin{array}{c}34.9 \pm 3.0 \\
(28.5-48.6) \\
8.6\end{array}$ & $\begin{array}{c}33.6 \pm 2.3 \\
(28.8-38.6) \\
6.9\end{array}$ & $\begin{array}{l}13.5 \pm 0.6 \\
(11.1-15.3) \\
4.5\end{array}$ & $\begin{array}{c}13.9 \pm 0.4 \\
(13.1-15.0) \\
2.9\end{array}$ \\
\hline Body width at anus & $\cdots$ & $\ldots$ & $\ldots$ & $\ldots$ & $\begin{array}{l}10.5 \pm 0.6 \\
(9.2-12.0) \\
5.3\end{array}$ & $\begin{array}{l}10.8 \pm 0.4 \\
(10.2-11.7) \\
3.3\end{array}$ \\
\hline Head region height & $\ldots$ & $\ldots$ & $\begin{array}{l}5.1 \pm 1.2 \\
(2.4-9.2) \\
23.3\end{array}$ & $\begin{array}{l}7.6 \pm 0.3 \\
(7.0-8.1) \\
3.9\end{array}$ & $\begin{array}{l}1.8 \pm 0.3 \\
(1.1-2.4) \\
13.8\end{array}$ & $\begin{array}{l}2.7 \pm 0.2 \\
(2.4-3.1) \\
6.5\end{array}$ \\
\hline Head region width & $\ldots$ & $\ldots$ & $\begin{array}{l}12.6 \pm 0.6 \\
(11.0-14.5) \\
5.0\end{array}$ & $\begin{array}{l}12.8 \pm 0.5 \\
(11.8-13.7) \\
3.8\end{array}$ & $\begin{array}{l}5.1 \pm 0.3 \\
(4.5-6.1) \\
5.3\end{array}$ & $\begin{array}{l}5.4 \pm 0.2 \\
(4.8-5.7) \\
2.9\end{array}$ \\
\hline \multirow[t]{2}{*}{ Stylet length } & $\begin{array}{c}14.7 \pm 1.3 \\
(11.1-19.0)\end{array}$ & $\begin{array}{c}14.1 \pm 0.3 \\
(13.6-14.6)\end{array}$ & $\begin{array}{l}23.0 \pm 1.0 \\
(20.0-24.7)\end{array}$ & $\begin{array}{c}23.5 \pm 0.6 \\
(21.7-24.3)\end{array}$ & $\begin{array}{l}10.6 \pm 0.8 \\
(9.2-13.0)\end{array}$ & $\begin{array}{c}11.1 \pm 0.3 \\
(10.4-11.9)\end{array}$ \\
\hline & 8.5 & 1.9 & 4.2 & 2.6 & 7.2 & 2.7 \\
\hline \multirow[t]{2}{*}{ Stylet knob height } & $\begin{array}{l}2.5 \pm 0.28 \\
(1.8-3.7)\end{array}$ & $\begin{array}{l}2.5 \pm 0.2 \\
(2.1-2.8)\end{array}$ & $\begin{array}{l}3.2 \pm 0.3 \\
(2.4-4.0)\end{array}$ & $\begin{array}{l}3.2 \pm 0.2 \\
(2.9-3.5)\end{array}$ & $\begin{array}{l}1.2 \pm 0.2 \\
(1.0-1.6)\end{array}$ & $\begin{array}{l}1.4 \pm 0.1 \\
(1.2-1.6)\end{array}$ \\
\hline & 11.1 & 7.1 & 9.9 & 4.8 & 12.4 & 7.0 \\
\hline \multirow[t]{2}{*}{ Stylet knob width } & $\begin{array}{c}4.3 \pm 0.3 \\
(3.2-5.0)\end{array}$ & $\begin{array}{l}4.6 \pm 0.2 \\
(4.1-5.1)\end{array}$ & $\begin{array}{c}5.1 \pm 0.3 \\
(4.2-5.8)\end{array}$ & $\begin{array}{l}5.6 \pm 0.3 \\
(5.1-6.1)\end{array}$ & $\begin{array}{l}2.1 \pm 0.2 \\
(1.6-2.9)\end{array}$ & $\begin{array}{l}2.6 \pm 0.1 \\
(2.3-2.8)\end{array}$ \\
\hline & 7.1 & 5.1 & 6.6 & 5.5 & 9.5 & 5.0 \\
\hline $\begin{array}{l}\text { Dorsal esophageal gland } \\
\text { orifice }\end{array}$ & $\begin{array}{l}4.81 \pm 0.89 \\
(2.8-6.8) \\
18.6\end{array}$ & $\begin{array}{l}3.2 \pm 0.3 \\
(2.8-4.0) \\
10.6\end{array}$ & $\begin{array}{l}3.4 \pm 0.8 \\
(2.1-7.9) \\
23.9\end{array}$ & $\begin{array}{l}2.5 \pm 0.5 \\
(1.4-3.6) \\
18.2\end{array}$ & $\begin{array}{l}3.6 \pm 0.6 \\
(2.4-5.3) \\
15.2\end{array}$ & $\begin{array}{l}2.8 \pm 0.3 \\
(2.2-3.4) \\
9.6\end{array}$ \\
\hline $\begin{array}{l}\text { Excretory pore to } \\
\text { anterior end }\end{array}$ & $\begin{array}{l}35.2 \pm 10.3 \\
(13.2-77.9) \\
29.1\end{array}$ & $\begin{array}{l}30.5 \pm 12.3 \\
(11.9-71.1) \\
40.3\end{array}$ & $\begin{array}{l}185.4 \pm 18.0 \\
(147.5-240.0) \\
9.7\end{array}$ & $\begin{array}{l}181.5 \pm 20.3 \\
(148.6-254.1) \\
11.2\end{array}$ & $\begin{array}{c}79.8 \pm 3.8 \\
(61.6-86.8) \\
4.7\end{array}$ & $\begin{array}{l}80.1 \pm 2.7 \\
(73.9-86.0) \\
3.3\end{array}$ \\
\hline Interphasmidial distance & $\begin{array}{c}24.2 \pm 3.6 \\
(15.7-35.7)\end{array}$ & $\begin{array}{c}22.1 \pm 2.8 \\
(16.7-28.1)\end{array}$ & & & & \\
\hline \multirow[t]{2}{*}{ Vulva length } & $\begin{array}{l}15.0 \\
25.8 \pm 3.1 \\
(14.3-34.3)\end{array}$ & $\begin{array}{l}12.7 \\
23.5 \pm 1.2 \\
(20.0-25.4)\end{array}$ & $\ldots$ & $\cdots$ & $\cdots$ & $\cdots$ \\
\hline & 12.0 & 5.3 & $\cdots$ & $\ldots$ & $\ldots$ & $\begin{array}{c}\ldots \\
\text { ued on next page) }\end{array}$ \\
\hline
\end{tabular}

\footnotetext{
a All measurements in micrometers with mean \pm standard deviation (range) coefficient of variation. Data for Portuguese isolates are means of seven isolates.
} 
M. hispanica displayed sequence divergences ranging from 0.5 to $1.5 \%$ when compared with the other species, and M. ethiopica (ItE) from 0.1 to $1.5 \%$ (Table 3).

Both NJ and ML trees obtained were similar; therefore, only the NJ tree is exhibited with bootstrap values (Figs. 6 and 7). The five Meloidogyne spp. with similar amplification products clustered separately. $M$. ethiopica and $M$. javanica were sister taxa to $M$. hispanica (PtHi3) but with lower bootstrap support (50\%; Fig. 6). The isolate ItE formed a clade with M. ethiopica with $94 \%$ bootstrap. M. incognita and M. arabicida were the most divergent species (Fig. 6; Table 3).

The tree obtained from NJ analysis of mtDNA sequences of several Meloidogyne spp. available in GenBank showed that all Meloidogyne spp. formed two well-supported clades (72 and 95\%) with the exclusion of $M$. graminis (Fig. 7). First, $M$. chitwoodi and $M$. fallax were clustered together with high bootstrap support (100\%) and as a sister taxon to $M$. graminicola (95\%). Second, M. hispanica formed a clade well supported (99\%) with M. thailandica,
M. arenaria, M. morocciensis, M. javanica, M. floridensis, $M$. incognita, M. ethiopica, M. paranaensis, and M. arabicida; however, the relationship within this clade was poor. This clade was a sister to M. haplanaria and M. mayaguensis. Another clade was formed by M. partityla and M. hapla (90\%; Fig. 7).

\section{Discussion}

Effective $M$. hispanica management programs require accurate and rapid identification tools for this nematode species. However, identification of Meloidogyne spp. is difficult due to morphological similarity between species, intraspecific variability, and the number of described Meloidogyne spp. (33).

Range values of the morphometric characteristics for adult females and males and $\mathbf{J} 2$ of the seven isolates overlapped or were within the expected range according to Hirschmann (27). The morphology of the different development stages of the $M$. hispanica isolates was similar to the original description (27). M. hispanica has several morphobiometric characteristics similar to other Meloi-

Table 2. (continued from preceding page)

\begin{tabular}{|c|c|c|c|c|c|c|}
\hline \multirow[b]{2}{*}{ Characteristic } & \multicolumn{2}{|c|}{ Females } & \multicolumn{2}{|c|}{ Males } & \multicolumn{2}{|c|}{ Second-stage juveniles } \\
\hline & $\begin{array}{l}\text { Portuguese } \\
\text { isolates }\end{array}$ & $\begin{array}{c}\text { Hirschmann } \\
1986\end{array}$ & $\begin{array}{l}\text { Portuguese } \\
\text { isolates }\end{array}$ & $\begin{array}{c}\text { Hirschmann } \\
1986\end{array}$ & $\begin{array}{l}\text { Portuguese } \\
\text { isolates }\end{array}$ & $\begin{array}{l}\text { Hirschmann } \\
1986\end{array}$ \\
\hline Vulva-anus distance & $\begin{array}{l}20.5 \pm 2.2 \\
(12.1-25.7) \\
11.0\end{array}$ & $\begin{array}{l}19.0 \pm 1.3 \\
(17.2-22.6) \\
\quad 6.7\end{array}$ & $\ldots$ & $\ldots$ & $\ldots$ & $\ldots$ \\
\hline Tail length & $\ldots$ & $\ldots$ & $\begin{array}{l}10.8 \pm 1.9 \\
(5.8-16.6) \\
17.7\end{array}$ & $\begin{array}{l}13.3 \pm 1.7 \\
(10.7-16.2) \\
13.1\end{array}$ & $\begin{array}{l}48.1 \pm 3.8 \\
(33.2-56.8) \\
7.8\end{array}$ & $\begin{array}{l}46.4 \pm 2.8 \\
(41.1-53.4) \\
6.1\end{array}$ \\
\hline Phasmids to tail end & $\ldots$ & $\cdots$ & $\begin{array}{l}13.1 \pm 2.9 \\
(7.1-20.8) \\
22.0\end{array}$ & $\begin{array}{l}14.4 \pm 2.3 \\
(10.3-19.4) \\
16.1\end{array}$ & . & - \\
\hline Spicule length & $\cdots$ & $\ldots$ & $\begin{array}{l}34.7 \pm 2.1 \\
(28.0-41.1) \\
6.0\end{array}$ & $\begin{array}{l}32.1 \pm 0.8 \\
(31.1-33.7) \\
2.4\end{array}$ & $\ldots$ & $\ldots$ \\
\hline Gubernacule length & $\ldots$ & $\cdots$ & $\begin{array}{l}8.1 \pm 0.8 \\
(5.8-11.8) \\
10.4\end{array}$ & $\begin{array}{l}8.3 \pm 0.5 \\
(7.4-9.3) \\
5.8\end{array}$ & $\ldots$ & $\ldots$ \\
\hline Testis length & $\ldots$ & $\cdots$ & $\begin{array}{l}949.3 \pm 180.1 \\
(471.4-1,357.1) \\
19.0\end{array}$ & $\begin{array}{l}808.4 \pm 113.6 \\
(650.0-1,150.0) \\
14.0\end{array}$ & $\ldots$ & $\ldots$ \\
\hline Ratios & & & & & & \\
\hline $\mathrm{a}$ & $\begin{array}{l}1.5 \pm 0.2 \\
(1.2-2.0) \\
10.1\end{array}$ & $\begin{array}{l}1.7 \pm 0.3 \\
(0.9-2.2) \\
17.0\end{array}$ & $\begin{array}{l}44.7 \pm 4.3 \\
(36.5-55.4) \\
9.6\end{array}$ & $\begin{array}{l}41.2 \pm 6.1 \\
(31.4-61.4) \\
14.8\end{array}$ & $\begin{array}{l}28.7 \pm 2.5 \\
(22.4-35.7) \\
8.6\end{array}$ & $\begin{array}{l}27.1 \pm 1.2 \\
(24.6-30.9) \\
4.5\end{array}$ \\
\hline $\mathrm{c}$ & $\ldots$ & $\ldots$ & $\begin{array}{c}176.7 \pm 36.9 \\
(104.7-350.4)\end{array}$ & $\begin{array}{l}128.1 \pm 19.0 \\
(98.2-172.6)\end{array}$ & $\begin{array}{c}8.7 \pm 0.9 \\
(5.8-12.8)\end{array}$ & $\begin{array}{c}8.5 \pm 0.4 \\
(7.7-9.4)\end{array}$ \\
\hline d & $\cdots$ & $\ldots$ & $\begin{array}{c}20.9 \\
\quad \ldots\end{array}$ & $\begin{array}{r}14.8 \\
\quad \ldots\end{array}$ & $\begin{array}{l}10.3 \\
4.6 \pm 0.4 \\
(3.3-5.6) \\
9.0\end{array}$ & $\begin{array}{l}4.3 \\
4.3 \pm 0.3 \\
(3.8-5.0) \\
6.5\end{array}$ \\
\hline $\begin{array}{l}\text { Body length/neck } \\
\text { length }\end{array}$ & $\begin{array}{l}3.8 \pm 0.6 \\
(2.4-5.3) \\
15.0\end{array}$ & $\begin{array}{l}3.7 \pm 0.8 \\
(2.5-5.9) \\
21.0\end{array}$ & $\cdots$ & $\ldots$ & - & \\
\hline $\begin{array}{l}\text { Head region } \\
\text { width/height }\end{array}$ & $\ldots$ & $\cdots$ & $\begin{array}{l}2.6 \pm 0.7 \\
(1.3-5.1) \\
24.9\end{array}$ & $\begin{array}{l}1.7 \pm 0.1 \\
(1.6-1.8) \\
2.9\end{array}$ & $\begin{array}{l}2.8 \pm 0.4 \\
(2.0-4.8) \\
14.9\end{array}$ & $\begin{array}{l}2.0 \pm 0.1 \\
(1.7-2.3) \\
6.9\end{array}$ \\
\hline $\begin{array}{l}\text { Stylet knob } \\
\text { width/height }\end{array}$ & $\begin{array}{l}1.7 \pm 0.2 \\
(1.1-2.4) \\
13.2\end{array}$ & $\begin{array}{l}1.9 \pm 0.2 \\
(1.6-2.2) \\
7.7\end{array}$ & $\begin{array}{l}1.6 \pm 0.2 \\
(1.2-2.2) \\
11.0\end{array}$ & $\begin{array}{l}1.7 \pm 0.1 \\
(1.5-2.0) \\
5.9\end{array}$ & $\begin{array}{l}1.7 \pm 0.3 \\
(1.2-2.8) \\
15.0\end{array}$ & $\begin{array}{l}1.8 \pm 0.1 \\
(1.6-2.2) \\
7.1\end{array}$ \\
\hline $\begin{array}{l}\text { Stylet length/body } \\
\text { width at stylet knobs }\end{array}$ & $\ldots$ & $\ldots$ & $\begin{array}{l}1.1 \pm 0.1 \\
(0.8-1.5) \\
8.0\end{array}$ & $\ldots$ & $\ldots$ & $\ldots$ \\
\hline $\begin{array}{l}\text { Excretory pore from } \\
\text { anterior end/stylet } \\
\text { length }\end{array}$ & $\begin{array}{l}2.4 \pm 0.7 \\
(0.8-4.8) \\
30.0\end{array}$ & $\ldots$ & (1) & $\ldots$ & $\ldots$ & $\ldots$ \\
\hline Percentages & & & & & & $\cdots$ \\
\hline $\begin{array}{l}\text { (Excretory pore to head } \\
\text { end/body length) } \times \\
100 \\
\mathrm{~T}\end{array}$ & $\cdots$ & $\cdots$ & $\begin{array}{l}10.1 \pm 1.0 \\
(7.1-13.3) \\
10.0 \\
51.3 \pm 8.0 \\
(28.3-69.7) \\
15.6\end{array}$ & $\begin{array}{l}10.9 \pm 1.7 \\
(8.2-18.1) \\
15.1 \\
48.7 \pm 8.2 \\
(32.7-62.2) \\
16.8\end{array}$ & $\begin{array}{l}19.1 \pm 1.2 \\
(14.0-25.8) \\
6.5\end{array}$ & $\begin{array}{c}20.4 \pm 0.6 \\
(19.0-21.7) \\
3.1\end{array}$ \\
\hline
\end{tabular}


dogyne spp., including $M$. arenaria, $M$. floridensis, and $M$. incognita, which has resulted in taxonomic confusion $(25,27,34)$. Therefore, the biometrical diagnostic characteristics need to be supported by other characteristics resulting from biochemical and molecular studies.

The esterase phenotypes of the seven $M$. hispanica isolates were similar (Hi4). The two major bands were used to characterize the isolates of this species because the two fainter bands can vary with the amount of protein and time of staining. This pattern is unique in $M$. hispanica and is very useful to differentiate this species from other Meloidogyne spp. (3,4,10-12,21,22,35).
The mtDNA-PCR-RFLP analysis was also an efficient methodology to discriminate $M$. hispanica from the other RKN species. The amplified product of $M$. hispanica (approximately 1,800 bp), using primers $\mathrm{C} 2 \mathrm{~F} 3$ and MRH106, has been reported in this study for the first time. These primers had been used to identify the major RKN species occurring in China (50). Taking into consideration that the amplified products with primers C2F3/MRH106 were approximately 130 bp larger than those obtained with primers $\mathrm{C} 2 \mathrm{~F} 3 / 1108$, our results for M. hapla (approximately $650 \mathrm{bp}$ ), M. chitwoodi (approximately 650 bp), M. mayaguensis (approximately $850 \mathrm{bp}$ ), M. javanica (approximately
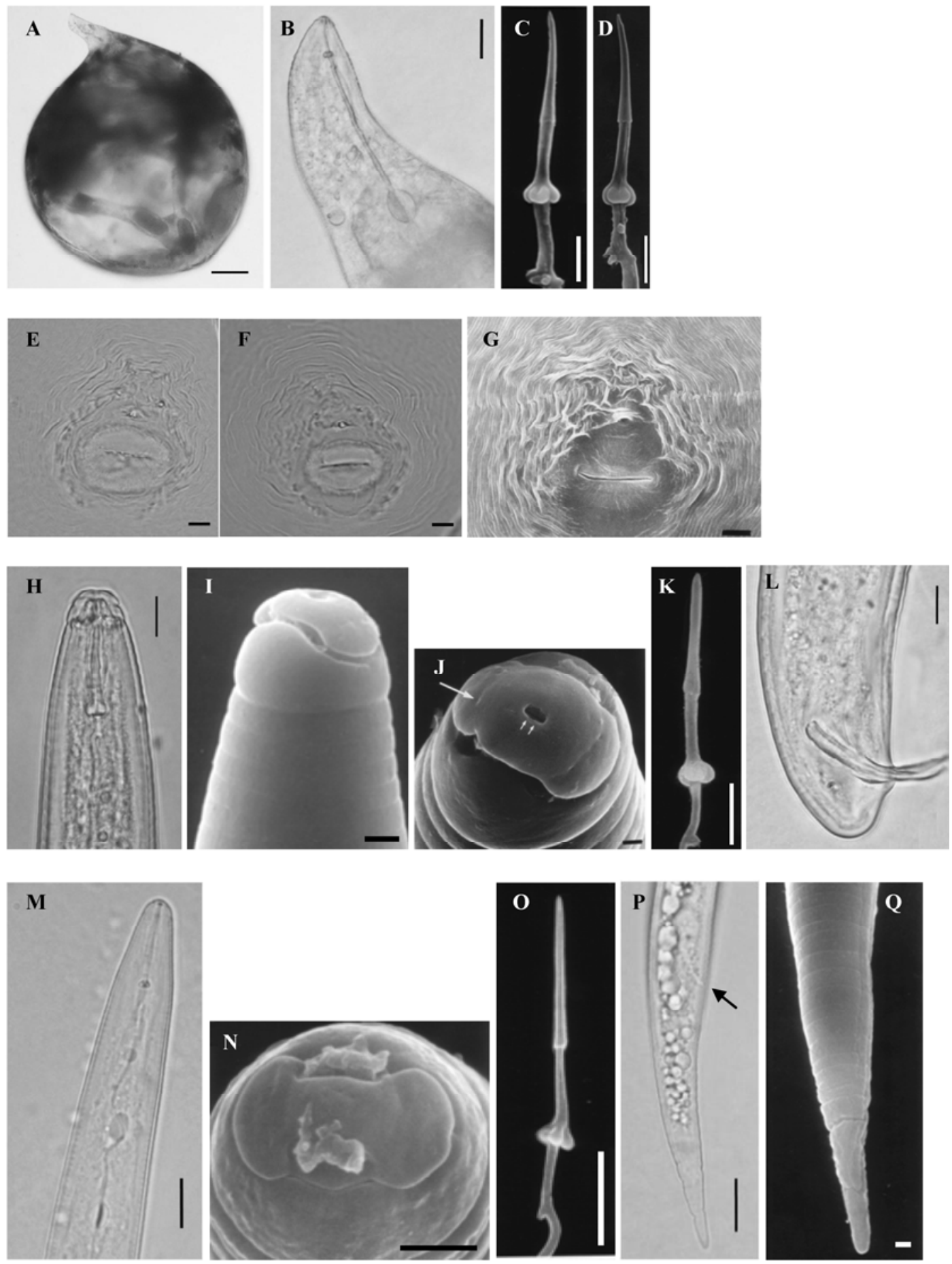

Fig. 1. A, B, E, F, H, L, M, and P, Light and C, D, G, I, J, K, N, O, and Q, scanning electron microscope photographs of Meloidogyne hispanica. Females: A, whole specimen; $\mathbf{B}$, anterior end and esophageal region; $\mathbf{C}$ and $\mathbf{D}$, excised stylets; and $\mathbf{E}-\mathbf{G}$, perineal patterns. Males: $\mathbf{H}$ and $\mathbf{I}$, anterior region in lateral view; J, head region showing cephalic sensilla (arrow) and inner labial sensilla (double arrow); K, excised stylet; and L, posterior region in lateral view. Second-stage juveniles: $\mathbf{M}$, anterior region; $\mathbf{N}$, head region; $\mathbf{0}$, excised stylet; and $\mathbf{P}$ and $\mathbf{Q}$, tail region with $\mathbf{P}$, anus and inflated rectum (arrow). Scale bars: $100 \mu \mathrm{m}(\mathrm{A}), 20 \mu \mathrm{m}(\mathrm{B}), 10 \mu \mathrm{m}(\mathrm{E}-\mathrm{H}, \mathrm{L}, \mathrm{M}$, and $\mathrm{P}), 5 \mu \mathrm{m}(\mathrm{C}, \mathrm{D}, \mathrm{K}$, and $\mathrm{O}), 2$ $\mu \mathrm{m}(\mathrm{I})$, and $1 \mu \mathrm{m}(\mathrm{J}, \mathrm{N}$, and $\mathrm{Q}$ ) 
$1,800 \mathrm{bp}$ ), and M. ethiopica (approximately $1,800 \mathrm{bp}$ ) agree with previous reports $(8,26,29,38,46,50)$. The $M$. arenaria isolate produced a fragment of approximately $1,300 \mathrm{bp}$, which agrees with other studies, except with the populations from the French West Indies which have produced a PCR product of approximately 1,700 bp $(8,29,38,46,50)$. Although $M$. incognita has been reported as having populations that produced two sizes of PCR products (approximately 1,500 and $1,700 \mathrm{bp}$ ) with $\mathrm{C} 2 \mathrm{~F} 3 / 1108$ primers, the Portuguese isolate produced a product with approximately 1,800 bp $(8,29,38,46)$.
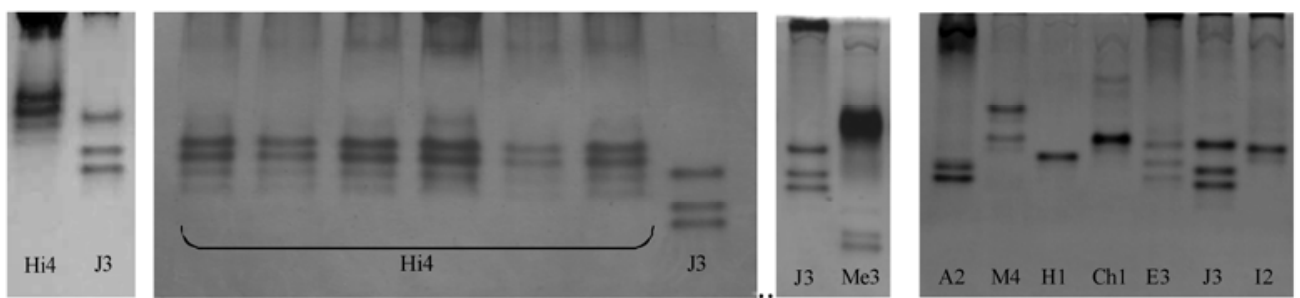

Fig. 2. Esterase phenotypes of protein homogenates from five egg-laying females of Meloidogyne spp. isolates included in this study. Hi4, Meloidogyne hispanica; $J 3, M$. javanica (reference isolate); Me3, M. megadora; A2, M. arenaria; M4, M. mayaguensis; H1, M. hapla; Ch1, M. chitwoodi (10 egg-laying females); E3, M. ethiopica; and I2, M. incognita.

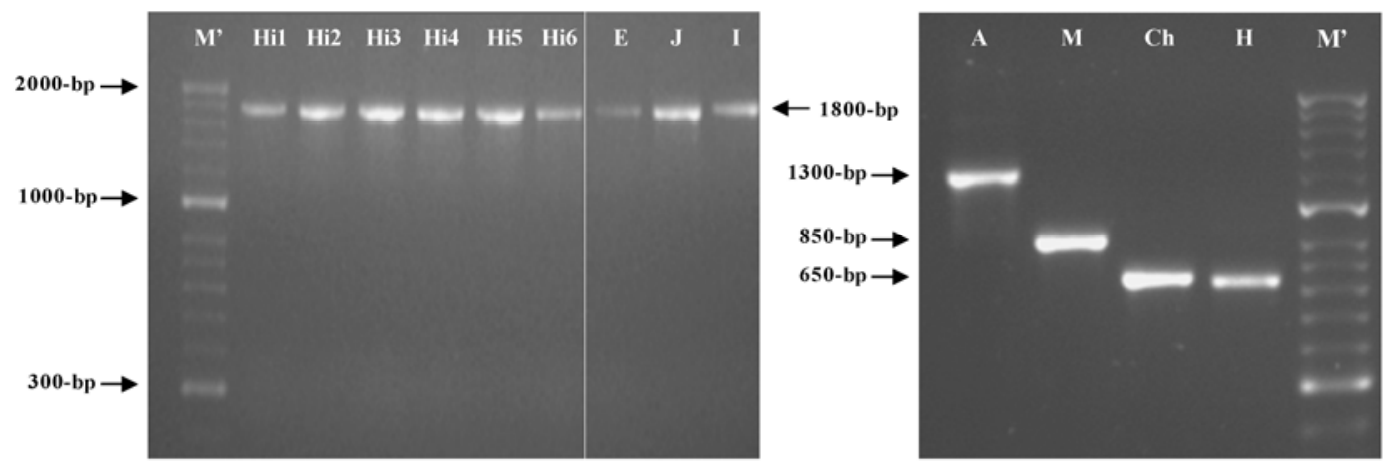

Fig. 3. DNA amplification products obtained from 13 isolates of eight Meloidogyne spp. using C2F3 and MRH106 primers. Hi2-Hi7, Meloidogyne hispanica; E, M. ethiopica; J, M. javanica; I, M. incognita; A, M. arenaria; M, M. mayaguensis; Ch, M. chitwoodi; H, M. hapla; and M', DNA marker (HyperLadder Il; Bioline).

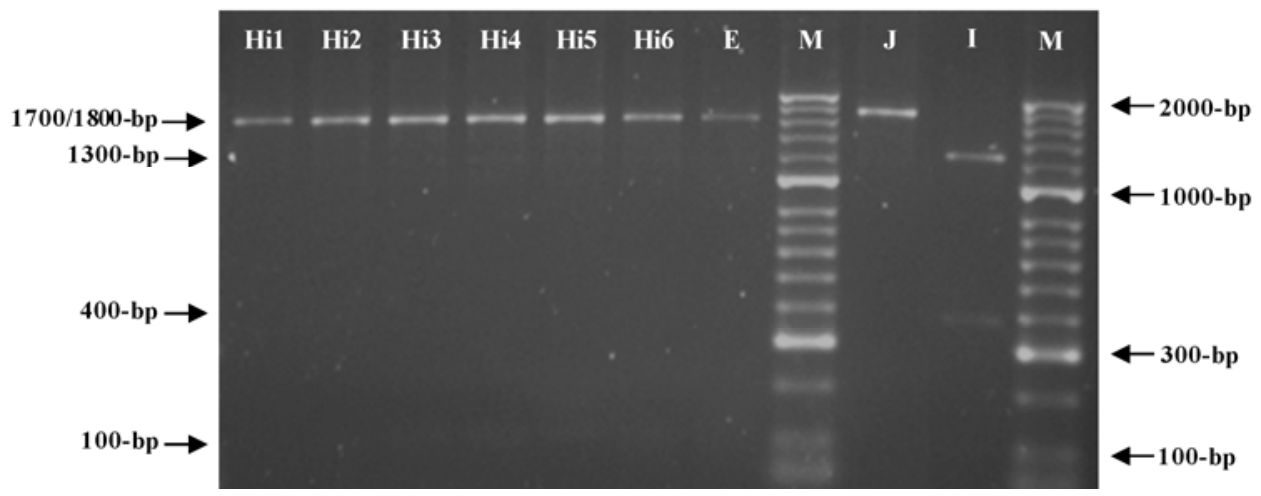

Fig. 4. Hinfl digestion patterns of the approximately 1,800-bp amplification products from Meloidogyne spp. after $8 \mathrm{~h}$ of digestion. Hi2-Hi7, Meloidogyne hispanica; E, M. ethiopica; J, M. javanica; I, M. incognita; and M, DNA marker (HyperLadder II; Bioline).

A

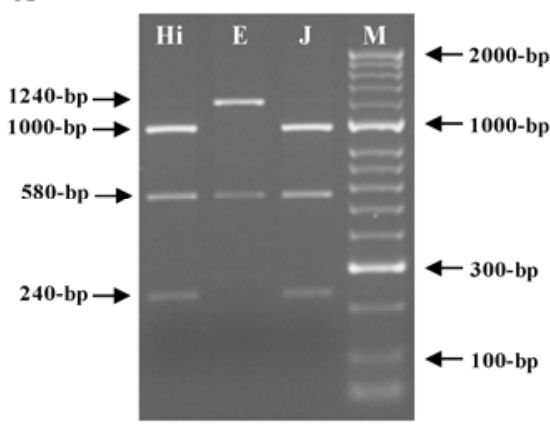

B

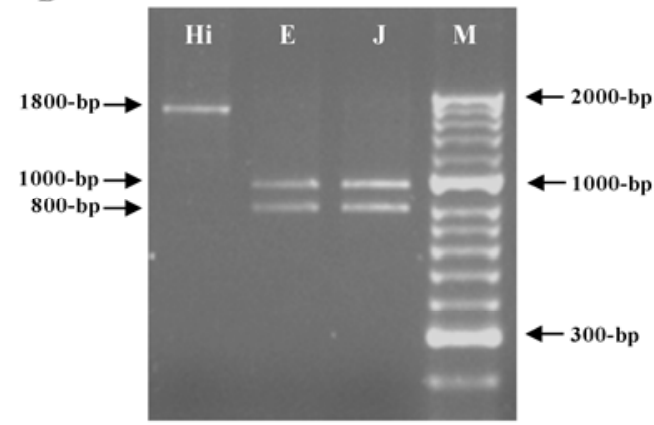

Fig. 5. A, Alul and B, Dralll digestion patterns of the approximately 1,800-bp amplification products from Meloidogyne spp. after 8 and $5 \mathrm{~h}$ of digestion. Hi, Meloidogyne hispanica (similar for all M. hispanica isolates); E, M. ethiopica; J, M. javanica; and M, DNA marker (HyperLadder II; Bioline). 
Table 3. Pairwise sequence divergences between Meloidogyne hispanica (PtHi3), M. arabicida (Mar, AY942852), M. ethiopica (ItE and Me, AY942848), M. incognita (Mi, AY635611; Mi1, FY159614; and Mi2, FJ159616), and M. javanica (Mj, AY635612 and Mj1, FJ159612) sequences of mtDNA using MEGA5

\begin{tabular}{|c|c|c|c|c|c|c|c|c|c|}
\hline Species & PtHi3 & ItE & Mar & Me & Mi & Mi1 & Mi2 & $\mathbf{M j}$ & Mj1 \\
\hline PtHi3 & & $\ldots$ & $\ldots$ & $\ldots$ & $\ldots$ & $\ldots$ & $\ldots$ & $\ldots$ & $\ldots$ \\
\hline $\mathrm{ItE}$ & 0.007 & $\ldots$ & $\ldots$ & $\ldots$ & $\ldots$ & $\ldots$ & $\ldots$ & $\ldots$ & $\ldots$ \\
\hline Mar & 0.015 & 0.015 & $\ldots$ & $\ldots$ & $\ldots$ & $\ldots$ & $\ldots$ & $\ldots$ & $\ldots$ \\
\hline $\mathrm{Me}$ & 0.005 & 0.001 & 0.013 & $\ldots$ & $\ldots$ & $\ldots$ & $\ldots$ & $\ldots$ & $\ldots$ \\
\hline $\mathrm{Mi}$ & 0.008 & 0.007 & 0.016 & 0.006 & $\ldots$ & $\ldots$ & $\ldots$ & $\ldots$ & $\ldots$ \\
\hline Mi1 & 0.006 & 0.006 & 0.014 & 0.005 & 0.003 & & $\ldots$ & $\ldots$ & $\ldots$ \\
\hline Mi2 & 0.006 & 0.006 & 0.014 & 0.005 & 0.003 & 0.001 & $\ldots$ & $\ldots$ & $\ldots$ \\
\hline $\mathrm{Mj}$ & 0.006 & 0.005 & 0.014 & 0.003 & 0.007 & 0.005 & 0.005 & $\ldots$ & $\ldots$ \\
\hline $\mathrm{Mj} 1$ & 0.005 & 0.004 & 0.013 & 0.003 & 0.007 & 0.005 & 0.005 & 0.000 & $\ldots$ \\
\hline
\end{tabular}

a Analyses were conducted using the Maximum Composite Likelihood model. All positions containing gaps and missing data were eliminated.
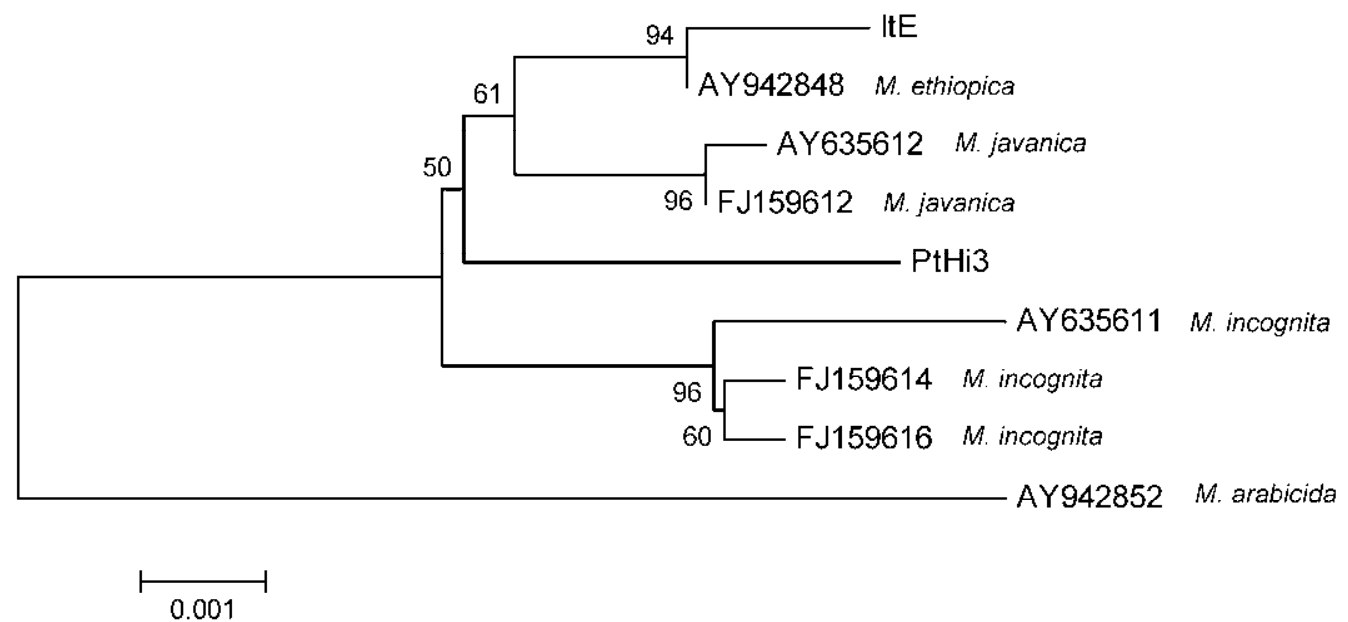

Fig. 6. Neighbor-joining tree based on mtDNA sequences of Meloidogyne spp. with approximate amplification product sizes to Meloidogyne hispanica (PtHi3) and M. ethiopica (ItE). The percentage of replicate trees in which the associated Meloidogyne spp. clustered together in the bootstrap test (1,000 replicates) is shown next to the branches. Evolutionary distances were computed using the Maximum Composite Likelihood method and all positions containing gaps and missing data were eliminated.

HinfI restriction patterns of the approximately $1,800 \mathrm{bp}$ amplified products discriminated $M$. incognita from the other species but no digestion occurred in $M$. javanica, which is in agreement with the results reported by $\mathrm{Xu}$ et al. (50). M. hispanica was distinguished from M. hapla and M. chitwoodi, M. mayaguensis, and $M$. arenaria by the size of the PCR products but showed the same size product of amplification as that of $M$. ethiopica, $M$. incognita, and M. javanica. M. hispanica could be differentiated from $M$. javanica and $M$. ethiopica by the size of amplified products after digestion with DraIII and AluI, as predicted by the restriction enzyme maps. The sequence of the Italian M. ethiopica isolate was identical to previous reports for this species, which confirmed the results obtained by isozyme analysis (E3). The RFLP strategy implemented required only one to four steps for quick identification of eight important and damaging Meloidogyne spp. based on variable mtDNA amplification products and respective nucleotide variations. This methodology could be adapted to single specimens for use in routine examination of soil samples where $\mathrm{J} 2$ are found.

Mitochondrial DNA has been used for molecular diagnostics at the species level and construction of phylogenies of RKN (7). The mtDNA region from $C O I I$ and 16s rRNA genes varies in length and encompasses an AT-rich noncoding sequence with different sizes, as a result of deletions and insertions $(7,29)$. The RKN species $M$. arabicida, $M$. arenaria, $M$. ethiopica, $M$. floridensis, $M$. hispanica, $M$. incognita, $M$. javanica, $M$. morocciensis, and $M$. paranaensis formed a well-supported clade, with the exclusion of $M$. mayaguensis and $M$. hapla. This group includes the mitotic parthenogenetic RKNs that possess the AT-rich region; except for $M$. floridensis, which reproduces by facultative meiotic parthenogenesis, and $M$. thailandica, for which the mode of reproduction has not yet been studied $(25,32)$. M. mayaguensis formed a second group with M. haplanaria (57\% of bootstrap support) and showed an amplified product for the COII/16s rRNA region different from all studied species (8). According to Eisenback et al. (20), M. haplanaria was distinct from other species, such as $M$. chitwoodi, $M$. fallax, and $M$. graminis (meiotic parthenogenetic pathogens); $M$. hapla (reproduction by facultative meiotic or mitotic parthenogenesis); and $M$. arenaria, $M$. incognita, and $M$. javanica (reproduction by mitotic parthenogenesis), which grouped with $M$. mayaguensis. On the other hand, $M$. partityla, which reproduces by obligatory mitotic parthenogenesis, was included together with species that reproduce by meiotic parthenogenesis and lack the ATrich region in the amplified product $(7,29)$. Although the mode of reproduction of $M$. hapla isolates used for mtDNA sequencing is not mentioned in the GenBank database, in general, the results support the hypothesis that the ancestral state of the genus is characterized by the absence of this AT-rich region, and the evolution of Meloidogyne spp. is related to the mode of reproduction, with amphimixis being the ancestral reproductive state of the genus $(7,47)$.

Considering the main clades, our results also agree with those obtained by Tigano et al. (46) for the 18S rRNA gene. Relationships between RKN species were not clarified for mtDNA, which limits the confidence of this molecule for species discrimination. Both NJ analyses showed that mtDNA sequences were not enough to differentiate $M$. hispanica and $M$. ethiopica from other species with morphological similarities, such as $M$. arenaria, M. floridensis, and $M$. incognita $(25,27)$. Thus, the examination of more than one molecular characteristic is very important for identification and evolution studies of a particular species. The MP analysis of the D2-D3 region of 28S rDNA and ITS revealed that $M$. hispanica formed a clade with high bootstrap support and distinct from $M$. arenaria, M. incognita, M. konaensis, and M. paranaensis. However, $M$. hispanica has been reported to have an $18 \mathrm{~S}$ rDNA sequence identical to M. ethiopica (35). 


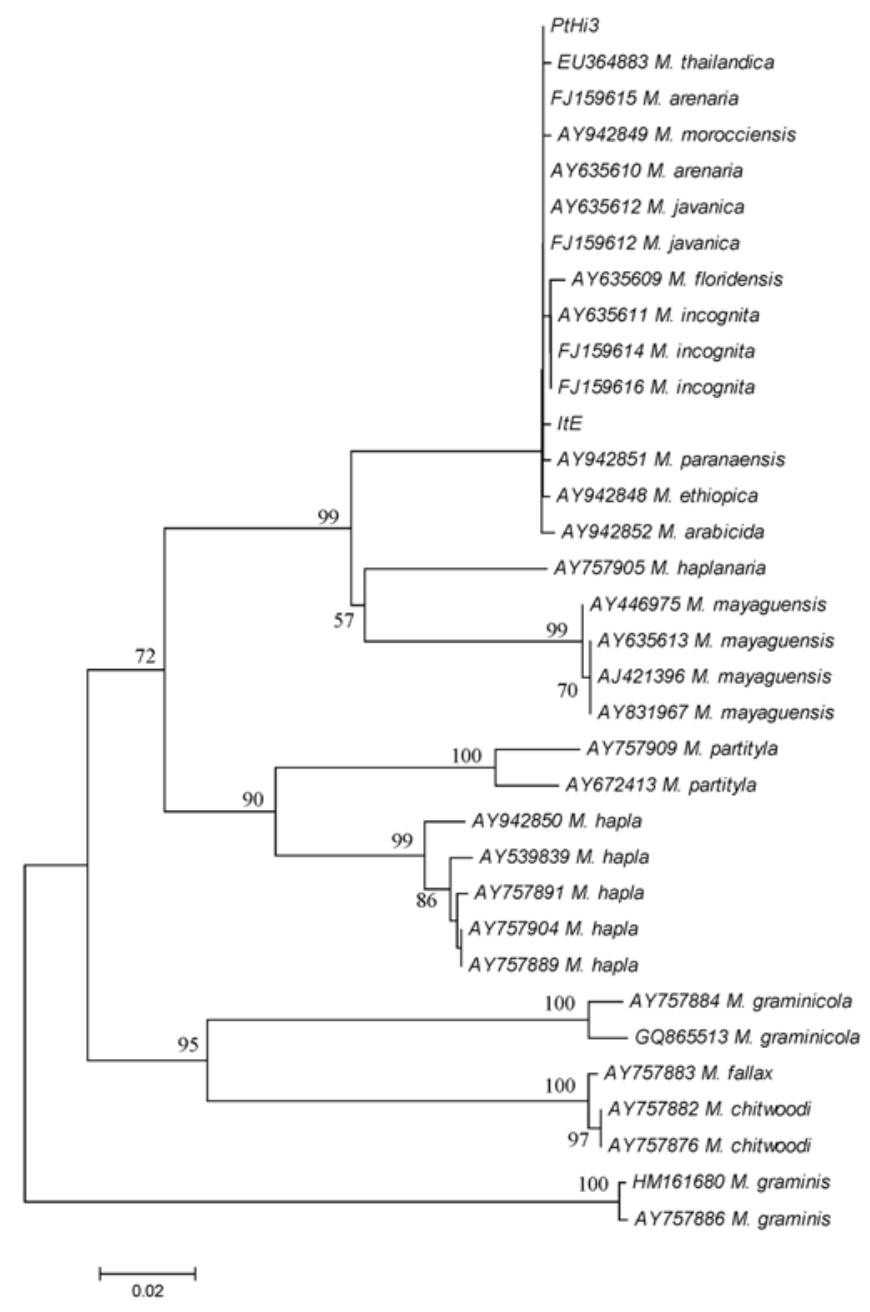

Fig. 7. Neighbor-joining tree based on analysis of alignment and adjusting the length of sequences of mtDNA region of Meloidogyne hispanica (PtHi3) and $M$. ethiopica (IE) with available sequences of other Meloidogyne spp. Evolutionary distances were computed using the Maximum Composite Likelihood method. All positions containing gaps and missing data were eliminated.

The reliable and rapid identification of $M$. hispanica, a potentially economically important plant pathogen, is of great importance for the diagnosis of this species and can be useful to monitor its distribution and spread. Isozyme analysis remains an effective methodology for precise identification and differentiation of $M$. hispanica (Hi4) when females are available in field root samples. Variability in mtDNA sequences among Meloidogyne spp. allowed the discrimination of $M$. hispanica and M. ethiopica from six other species studied by PCR-RFLP, providing a new tool for Meloidogyne spp. identification based on $\mathrm{J} 2$, the most common stage found in the soil, eliminating the need to use females from roots of field samples or to establish a culture in the laboratory. However, it will be necessary to analyze a broad range of $M$. hispanica isolates to validate the obtained results and strengthen the potential applicability of the mtDNA-PCR-RFLP analysis in diagnosis.

\section{Acknowledgments}

This research was supported by FEDER funds through the "Programa Operacional Factores de Competitividade-COMPETE" and by national funds through FCT-Fundação para a Ciência e a Tecnologia under the project PTDC/AGRAAM/103873/2008. C. Maleita was supported by an FCT-MCTES grant (SFRH/BD/24275/2005) supported by QREN funds through the "Programa Operacional Potencial Humano". Rothamsted Research receives grant-aided support from the Biotechnological and Biological Sciences Research Council of the United Kingdom.

\section{Literature Cited}

1. Abrantes, I. M. de O., and Santos, M. S. N. de A. 1989. A technique for preparing perineal patterns of root-knot nematodes for scanning electron microscopy. J. Nematol. 21:138-139.

2. Abrantes, I. M. de O., and Santos, M. S. N. de A. 1991. Meloidogyne lusitanica $\mathrm{n}$. sp. (Nematoda: Meloidogynidae), a root-knot nematodes parasitizing olive tree (Olea europaea L.). J. Nematol. 23:210-224.

3. Abrantes, I. M. de O., Santos, M. S. N. de A., and Vovlas, N. 1995. Studies on Meloidogyne megadora found in coffee plantations in República de S. Tomé e Príncipe. (Abstr.) Nematologica 41:278.

4. Abrantes, I. M. de O., Vieira dos Santos, M. C., Conceição, I. L. P. M. da Santos, M. S. N. de A., and Vovlas, N. 2008. Root-knot and other plantparasitic nematodes associated with fig trees in Portugal. Nematol. Mediterr. 36:131-136.

5. Almeida, A. M. S. F. de, and Santos, M. S. N. de A. 2002. Resistance and host-response of selected plants to Meloidogyne megadora. J. Nematol. 34:140-142.

6. Almeida, A. M. S. F. de, Santos, M. S. N. de A., and Ryan, M. F. 1997. Host status of selected plant species for Meloidogyne megadora. Nematropica 27:1-6.

7. Blok, V. C., and Powers, T. O. 2009. Biochemical and molecular identification. Pages 98-118 in: Root-Knot Nematodes. R. N. Perry, M. Moens, and J. L. Starr, eds. CABI Publishing, Wallingford, UK.

8. Blok, V. C., Wishart, J., Fargette, M., Berthier, K., and Phillips, M. S. 2002. Mitochondrial DNA differences distinguishing Meloidogyne mayaguensis from the major species of tropical root-knot nematodes. Nematology 4:773781.

9. Brito, J. A., Kaur, R., Cetintas, R., Stanley, J. D., Mendes, M. L., McAvoy, E. J., Powers, T. O., and Dickson, D. W. 2008. Identification and isozyme characterisation of Meloidogyne spp. infecting horticultural and agronomic crops, and weed plants in Florida. Nematology 10:757-766.

10. Carneiro, R. M. D. G., Almeida, M. R. A., and Gomes, A. C. M. M. 2004. First record of Meloidogyne hispanica Hirschmann, 1986 on squash in State of Bahia, Brazil. Nematol. Brasil. 28:215-218.

11. Carneiro, R. M. D. G., Randig, O., Almeida, M. R. A., and Gomes, A. C. M M. 2004. Additional information on Meloidogyne ethiopica Whitehead, 1968 (Tylenchida: Meloidogynidae), a root-knot nematode parasitising kiwi fruit and grape-vine from Brazil and Chile. Nematology 6:109-123.

12. Carneiro, R. M. D. G., Tigano, M. S., Randig, O., Almeida, M. R. A., and Sarah, J.-L. 2004. Identification and genetic diversity of Meloidogyne spp. (Tylenchida: Meloidogynidae) on coffee from Brazil, Central America and Hawaii. Nematology 6:287-298.

13. Castillo, P., Di Vito, M., Vovlas, N., and Jiménez-Díaz, R. M. 2001. Hostparasite relationships in root-knot disease of white mulberry. Plant Dis. 85:277-281.

14. Cenis, J. L., Opperman, C. H., and Triantaphyllou, A. C. 1992. Cytogenetic, enzymatic, and restriction fragment length polymorphism variation of Meloidogyne spp. from Spain. Phytopathology 82:527-531.

15. Cofcewicz, E. T., Carneiro, R. M. D. G., Randig, O., Chabrier, C., and Quénéhervé, P. 2005. Diversity of Meloidogyne spp. on Musa in Martinique, Guadeloupe and French Guiana. J. Nematol. 37:313-322.

16. Conceição, I. L. P. M. da, Cunha, M. J. M. da, Feio, G., Correia, M., Vieira dos Santos, M. C., Abrantes, I. M. de O., and Santos, M. S. N. de A. 2009 Root-knot nematodes, Meloidogyne spp., on potato in Portugal. Nematology 11:311-313.

17. Dalmasso, A., and Bergé, J. B. 1978. Molecular polymorphism and phylogenetic relationship in some Meloidogyne spp.: Application to the taxonomy of Meloidogyne. J. Nematol. 10:323-332.

18. Edgar R. C. 2004. MUSCLE: Multiple sequence alignment with high accuracy and high throughput. Nucleic Acids Res. 32:1792-1797.

19. Eisenback, J. D. 1985. Techniques for preparing nematodes for scanning electron microscopy. Pages 79-105 in: An Advanced Treatise on Meloidogyne, Vol. II. Methodology. K. R. Barker, C. C. Carter, and J. N. Sasser, eds. A cooperative publication of the Department of Plant Pathology and the United States Agency for International Development, North Carolina State University Graphics, Raleigh.

20. Eisenback, J. D., Bernard, E. C., Starr, J. L., Lee, T. A., Jr., and Tomaszewski, E. K. 2003. Meloidogyne haplanaria n. sp. (Nematoda: Meloidogynidae), a root-knot nematode parasitizing peanut in Texas. J. Nematol. 35:395-403.

21. Esbenshade, P. R., and Triantaphyllou, A. C. 1985. Use of enzyme phenotypes for identification of Meloidogyne species. J. Nematol. 17:6-20.

22. Fargette, M. 1987. Use of the esterase phenotype in the taxonomy of the genus Meloidogyne. 2. Esterase phenotypes observed in West African populations and their characterization. Rev. Nématol. 10:45-56.

23. Felsenstein, J. 1985. Confidence limits on phylogenies: An approach using the bootstrap. Evolution 39:783-791.

24. Hall, T. A. 1999. BioEdit: A user friendly biological sequence alignment editor and analyses program for windows 95/98/NT. Nucleic Acids Symp. Ser. 41:95-98

25. Handoo, Z. A., Nyczepir, A. P., Esmenjaud, D., van der Beek, J. G., Castagnone-Sereno, P., Carta, L. K., Skantar, A. M., and Higgins, J. A. 2004. Morphological, molecular, and differential-host characterization of Meloidogyne floridensis $\mathrm{n}$. sp. (Nematoda: Meloidogynidae), a root-knot nematode parasitizing peach in Florida. J. Nematol. 36:20-35.

26. Handoo, Z. A., Skantar, A. M., Carta, L. K., and Schmitt, D. P. 2005. Morphological and molecular evaluation of a Meloidogyne hapla population 
damaging coffee (Coffea arabica L.) in Maui, Hawaii. J. Nematol. 37:136145 .

27. Hirschmann, H. 1986. Meloidogyne hispanica n. sp. (Nematoda: Meloidogynidae), the "Seville Root-Knot Nematode". J. Nematol. 18:520532.

28. Janati, A., Bergé, J.-B., Triantaphyllou, A. C., and Dalmasso, A. 1982. Nouvelles données sur l'utilisation des isoestérases pour l'identification des Meloidogyne. Rev. Nématol. 5:147-154.

29. Jeyaprakash, A., Tigano, M. S., Brito, J., Carneiro, R. M. D. G., and Dickson, D. W. 2006. Differentiation of Meloidogyne floridensis from $M$. arenaria using high-fidelity PCR amplified mitochondrial AT-rich sequences. Nematropica 36:1-12.

30. Jukes, T. H., and Cantor, C. R. 1969. Evolution of protein molecules. Pages 21-132 in: Mammalian Protein Metabolism. H. N. Munro, ed. Academic Press, New York.

31. Karssen, G., 2004. Nieuwe wortelknobbelaaltjes en opvallende waarnemingen in Europa. Gewasbescherming 5:245-246.

32. Karssen, G., and Moens, M. 2006. Root-knot nematodes. Pages 59-90 in: Plant Nematology. R. N. Perry, and M. Moens, eds. CABI Publishing, Wallingford, UK.

33. Karssen, G., and van Hoenselaar, T. 1998. Revision of the genus Meloidogyne Göldi, 1982 (Nematoda: Heteroderidae) in Europe. Nematologica 44:713-788.

34. Kleynhans, K. P. N. 1993. Meloidogyne hispanica Hirschmann, 1986 and M. ethiopica Whitehead, 1968 in South Africa (Nemata: Heteroderidae). Phytophylactica 25:283-288.

35. Landa B. B., Palomares Rius, J. E., Vovlas, N., Carneiro, R. M. D. G., Maleita, C. M. N., Abrantes, I. M. de O., and Castillo, P. 2008. Molecular characterization of Meloidogyne hispanica (Nematoda, Meloidogynidae) by phylogenetic analysis of genes within the rDNA in Meloidogyne spp. Plant Dis. 92:1104-1110

36. Pais, C. S., Abrantes, I. M. de O., Fernandes, M. F. M., and Santos, M. S. N. de A. 1986. Técnica de electroforese aplicada ao estudo das enzimas dos nemátodes-das-galhas-radiculares, Meloidogyne spp. Ciênc. Biol. Ecol. Sist. 6:19-34

37. Piotte, C., Castagnone-Sereno, P., Uijthof, J., Abad, P., Bonjiovanni, M., and Dalmasso, A. 1992. Molecular characterization of species and populations of Meloidogyne from various geographic origins with repeated-DNA homologous probes. Fundam. Appl. Nematol. 15:271-276.

38. Powers, T. O., and Harris, T. S. 1993. A polymerase chain reaction method for identification of five major Meloidogyne species. J. Nematol. 25:1-6.

39. Randig, O., Bongiovanni, M., Carneiro, R. M. D. G., and CastagnoneSereno, P. 2002. Genetic diversity of root-knot nematodes from Brazil and development of SCAR markers specific for the coffee-damaging species. Genome 45:862-870.

40. Randig, O., Leroy, F., Bongiovanni, M., and Castagnone-Sereno, P. 2001.
RAPD characterization of single females of the root-knot nematodes, Meloidogyne spp. Eur. J. Plant Pathol. 107:639-643.

41. Saitou, N., and Nei, M. 1987. The neighbor-joining method: A new method for reconstructing phylogenetic trees. Mol. Biol. Evol. 4:406-425.

42. Stanton J., Hugall, A., and Moritz, C. 1997. Nucleotide polymorphisms and an improved PCR-based mtDNA diagnostic for parthenogenetic root-knot nematodes (Meloidogyne spp.). Fundam. Appl. Nematol. 20:261-268.

43. Tamura, K., Nei, M., and Kumar, S. 2004. Prospects for inferring very large phylogenies by using the neighbor-joining method. PNAS 101:1103011035.

44. Tamura, K., Peterson, D., Peterson, N., Stecher, G., Nei, M., and Kumar, S. 2011. MEGA5: Molecular evolutionary genetics analysis using Maximum Likelihood, Evolutionary Distance, and Maximum Parsimony Methods. Mol. Biol. Evol. doi:10.1093/molbev/msr121

45. Thompson, J. D., Higgins, D. G., and Gibson, T. J. 1994. CLUSTAL W: Improving the sensitivity of progressive multiple sequence alignment through sequence weighting, position-specific gap penalties and weight matrix choice. Nucleic Acids Res. 22:4673-4680.

46. Tigano, M. S., Carneiro, R. M. D. G., Jeyaprakash, A., Dickson, D. W., and Adams, B. J. 2005. Phylogeny of Meloidogyne spp. based on 18S rDNA and the intergenic region of mitochondrial DNA sequences. Nematology 7:851862.

47. Triantaphyllou, A. C. 1985. Cytogenetics, cytotaxonomy and phylogeny of root-knot nematodes. Pages 113-126 in: An Advanced Treatise on Meloidogyne, Vol. I: Biology and Control. J. N. Sasser and C.C. Carter, eds. A cooperative publication of the Department of Plant Pathology and the United States Agency for International Development. North Carolina State University Graphics, Raleigh.

48. Trudgill, D. L., Bala, G., Blok, V. C., Daudi, A., Davies, K. G., Gowen, S R., Fargette, M., Madulu, J. D., Mateille, T., Mwageni, W., Netscher, C., Phillips, M. S., Sawadogo, A., Trivino, C. G., and Voyoukallou, E. 2000. The importance of tropical root-knot nematodes (Meloidogyne spp.) and factors affecting the utility of Pasteuria penetrans as a biocontrol agent. Nematology 2:823-845.

49. van der Wurff, A. W. G., Janse, J., Kok, C. J., and Zoon, F. C. 2010. Biological Control of Root Knot Nematodes in Organic Vegetable and Flower Greenhouse Cultivation. Wageningen UR Greenhouse Horticulture, Bleiswijk, The Netherlands.

50. Xu, J., Liu, P., Meng, Q., and Long, H. 2004. Characterisation of Meloidogyne species from China using isozyme phenotypes and amplified mitochondrial DNA restriction fragment length polymorphism. Eur. J. Plant Pathol. 110:309-315.

51. Zijlstra, C. 2000. Identification of Meloidogyne chitwoodi, M. fallax and M. hapla based on SCAR-PCR: A powerful way of enabling reliable identification of populations or individuals that share common traits. Eur. J. Plant Pathol. 106:283-290. 